\title{
Regionale ressursmiljøer for selvmordsforebygging og -forskning i helseregionene Nord, Midt og Vest
}

v/H ans Lander, Venke $A$ arethun og M ålfrid Litlere

\section{Senter for forebygging av selvmord i Nord-Norge}

Senter for forebygging av selvmord i N ord-N orge er organisert under Psykiatrisk forsknings- og utviklingsavdeling ved U niversi tetssykehuset N ord-N orge (UN N ), og det ble etablert i 1996. Det har sine lokaler tilknyttet de psykiatriske avdelingene på Å sgård, i Tromsø.

I 2005 skal forankringen av senteret som en permanent virksomhet være på plass. D ette arbeidet skjer innenfor rammen av Sosial- og helsedirektoratets arbeid med fremtidig organisering av den regionale selvmords-, volds- og traumekompetansen. A nsatte ved senteret ved årsskiftet 2003/2004:

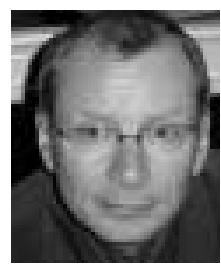

$\mathrm{H}$ ans $\mathrm{L}$ ander (100\%) er fagkonsulent og leder.

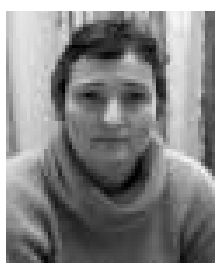

Ingrid $\mathrm{N}$ esje $(100 \%)$ er fagkonsulent.

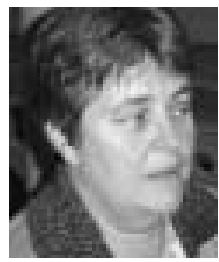

A gneta Ljungberg (50\%), er psykolog og lokalisert ved N ordlandssykehuset, Voksenpsykiatrisk poliklinikk i Fauske, med DBT som arbeidsfelt.

H arriet Johansen (10\%) er konsulent og kontormedarbeider. U ndervisningsprogrammet VIVAT er samlokalisert med senteret, og fagmiljøene trekker veksler på hverandre i det daglige arbeidet.

\section{Virksomhet:}

Senteret arbeider med å sikre gode oppføl gings- og behandlingsrutiner i helsetjenesten i regionen for mennesker i selvmordskrise og for etterlatte ved selvmord.

H ovedfokus er nå psykisk helsevern, der vi arbeider med kompetanseh eving og kvalitetssikring på psykiatriske sykehus og DPS'er.

Senteret er en aktiv part i implementering av dial ektisk atferdsterapi (DBT) i landsdelen, for tiden i Fauske/Bodø og Tromsø. DBT brukes i flere andre land som en anerkjent behandlingstilnærming til mennesker med personlighetsforstyrrelse og selvmordsproblematikk.

A ndre oppgaver er arbeid med etterlatte ved selvmord og samarbeid med LEVE (Landsforeningen for etterlatte ved selvmord).

Vi arrangerer videre ulike seminar og konferanser og tar også enkel tståen de undervisningsoppdrag i utdannings-institusjoner, kommuner m.m.

Vi kan nås på følgende måter:

Postadresse:

Senter for forebygging av selvmord i $\mathrm{N}$ ord-N orge

U N N , A sgård

Postboks 6124, 9291 Tromsø

Telefon: 77627819 / Telefaks: 77627530

harriet.johansen@unn.no eller selvmord@unn.no

www.unn.no/selvmord

\section{Regionalt ressurssenter for selvmordsforskning og -forebygging i Midt-Norge}

Regionalt ressurssenter for selvmordsforskning og -forebygging i M idt-N orge ligger i Trondheim. Vi er organisert under N TN U, Det medisinske fakultet, Institutt for nevromedisin. Dette er en foreløpig organisering i påvente av Sosial- og hel sedirektoratets utredning om fremtidig organisering av regional kompetanse på selvmords-, volds- og traumefeltet i helseregion Midt.

Vi er to nyansatte ved senteret:

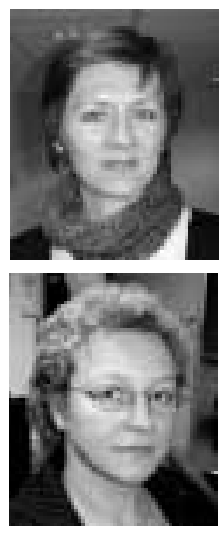

Venke $\mathbf{A}$ arethun ( $100 \%$ ) er ansatt som leder. venke.aarethun@medisin.ntnu.no

B ente Espeland ( $100 \%$ ) er ansatt som rådgiver. Bente.espeland@medisin.ntnu.no

Siri A akre Kolstad har vært ansatt i $20 \%$ stilling som sekretær siden 2001.

\section{Virksomhet:}

I påvente av Sosial- og helsedirektoratets avklaring om fremtidig organisering er målet og ønsket vårt å videreføre det arbeidet som har vært drevet ved ressurssenteret i mange år:

Vi har etablert kontakt med det psykiske helsevern i Trondheim, samt Trondheim kommune, der vi blant annet planlegger undervisning og veiledning. U ndervisningen på høgskolene i regionen vil bli videreført. Vi planlegger en nettverkskonferanse til høsten.

Selv om vi har bred erfaring fra psykiatri og rusomsorg, er selvmordsforebygging et relativt nytt område for oss begge og vi ser det som viktig å bygge opp egen kompetanse. Begge har starta ELF-utdanning (elementær forskerutdanning). I den forbindelse skal vi samarbeide med $\mathrm{H}$ eidi $\mathrm{H}$ jelmeland på et forskningsprosjekt om holdninger til selvmord.

Vi ser gjerne at de som tidligere har hatt kontakt med senteret, tar kontakt med oss.

Besøksadresse: $\varnothing$ stmarkveien 15, 7041 Trondheim.

Postadresse:

Regionalt ressurssenter for selvmordsforskning og -forebygging, M TFS, IN M , 7489 Trondheim.

TIf: Bente Espeland 73864649

TIf: Venke A arethun 73864685 


\section{Ressursmiliø for forebygging av selvmord i helseregion Vest}

Ressursmiljø for forebygging av selvmord i hel seregion Vest er organisert som et nettverk med stillinger i 3 av de 4 helseforetakene. Dette er en foreløpig organisering i påvente av Sosialog hel sedirektoratets utredning om fremtidig organisering av regional kompetanse på selvmords-, volds- og traumefeltet i region Vest.

For tiden arbeider disse personene i ressursmiljø V est:

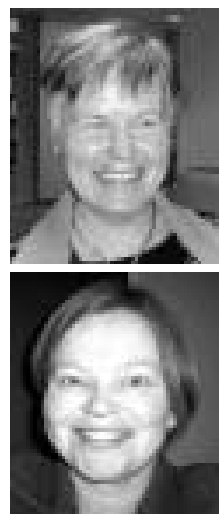

Målfrid L itlere (100\%), er tilknyttet $\mathrm{H}$ else Bergen og har koordinatorfunksjon for regionen.

malfrid.litlere@helse-bergen.no

G udrun A ustad ( $50 \%$ ) er prosjektleder i H else Stavanger og er administrativt knyttet til Psykiatrisk klinikk ved Sentralsjukehuset i Rogaland. gau@sir.no

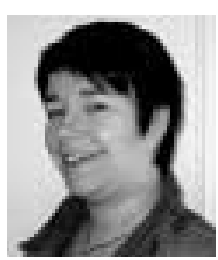

Else-H elen Stokkvik (50 \%) er koordinator for miljøet i $\mathrm{H}$ augesund og er administrativt knyttet til Psykiatrisk klinikk ved $\mathrm{H}$ augesund sjukehus. else.helen.stokkvik@helse-fonna.no

Virksomhet:

Ressursmiljøet arbeider i hovedsak med å videreutvikle behandlingskjeden, samt gi veiledning og undervisning. De ansatte bistår sykehus, kommuner og bydeler med å utvikle og kvalitetssikre rutiner for behandling og oppfølging av mennesker i selvmordskriser. Det arbeides også med å innføre slike rutiner på sykehus som tidligere ikke har hatt noen. En viktig oppgave er også arbeid med etterlatte. Det er et aktivt samarbeid med LEVE (Landsforeningen for etterlatte ved selvmord), som har lokallag i de tre fylkene her vest.

Innen psykisk helsevern settes det nå i gang en forløpstudie av selvmordsutsatte pasienter som legges inn i psykiatrisk akuttmottak. Prosjektet som eies av psykiatrisk divisjon $\mathrm{H}$ el se Bergen, ledes av cand.san. Liv M ellesdal. Prosjektet vil være knyttet til Psykiatrisk Institutt, U iB og SSFF, U iO.

Forebyggingsforum arrangeres to ganger årlig i Bergen. Forumet er et dagsseminar som tar opp temaer vedrøren de sel vmordsforebygging og samler 90-120 fagpersoner.

U ndervisningsprosjektet Vivat har ca 20 kursledere i region Vest, og "Førstehjelpskurs ved sel vmordsfare" holdes jevnlig. Det kan også gjerne arrangeres kurs for interesserte, f. eks for kommuner, bydeler, helsefagskoler, frivillige organisasjoner $\mathrm{mm}$. Dette gjelder også instanser i Sogn og Fjordane som for tiden ikke har Vivat-kursledere i aktiv tjeneste.

Ressursmiljøet i hel seregion Vest vil være en samarbeidspartner og tilbyr støtte og veiledning til fagpersoner angående selvmordsforebyggen de tiltak, både på systemnivå og mht. kompetansehevende tiltak.

Ta kontakt med oss:

M ålfrid Litlere, Tiltak mot selvmord Fjell og A rstad DPS, Solheimsgt. 23 b Postadr: Pb 2377 Solheimsviken, 5824 Bergen TIf. 55384108

malfrid.litlere@helse-bergen.no

\section{Dagskonferanse og landsmøte 8.-9. mai i Tromsø}

\section{v/Terese G røm}

Temaet for dagskonferansen er i år "Unge voksne etterlatte", et satsingsområde for LEVE. Foreningens 5. dagskonferanse og landsmøte er et resultat av et noert samarbeid mellom de tre nordlige fylkene; Finnmark, Troms og Nordland.

I sin strategiske handlingsplan 2002 2005 satser LEVE sterkt på unge etterlatte som gruppe: U nge LEV E er etablert. Fylkeslagene oppfordres til, og er allerede i gang med, å rekruttere en ungdomsrepresentant inn i fylkesstyrene. Dessuten er det bevilget midler av H else og R ehabilitering til det treårige prosjektet "Styrket omsorgsapparat til unge etterlatte ved selvmord". På bakgrunn av denne viktige satsingen er temaet for årets dagskonferanse "U nge voksne etterlatte".

I LEVE er det et vidt aldersspenn i kategorien unge/ungdom. Ved denne konferansen vil det primært handle om al dersgruppen 20-30 år, hvor samtalen skal stå i sentrum. H vordan oppleves det å være ung i en familie når sel vmordet skjer? H vilke konsekvenser gir det for livet videre? Tre unge etterlatte ved selvmord vil delta i en samtale med prest og leder av $\mathrm{N}$ ordland fylkeslag, G unnar K ristiansen. Kari Dyregrov ved Senter for krisepsykologi i Bergen vil deretter gi oss et innblikk i hvilke reaksjoner et så traumatisk tap som selvmord kan gi unge mennesker. Dyregrov som er sosiolog og forsker, er den eneste i N orge som har tatt doktorgraden på etterlatte ved selvmord. $\mathrm{H}$ un disputerte i november 2003 med avhandlingen The loss of a child by suicide, SID S, and accidents: consequences, needs and provisions of help.

LEV E har tidligere hatt gode erfaringer med samtale i smågrupper ved konferansene. Samtalegrupper vil derfor få betydelig plass også i årets program. Engasjementet øker blant del takerne. M uligheten til å komme med innspill oppleves lettere, og ikke minst, deltakerne har en mulighet til å komme tettere på hverandre og selvmords- og etterlattetematikken. D ette er til glede og nytte både for etterlatte, fagpersoner og for andre interesserte som er til stede. LEVE oppfordrer derfor alle fagpersoner som i en eller annen sammenheng har tilknytning til selvmord og/eller etterlatte i sitt daglige virke, til å delta. Vi ønsker dere velkommen til en maihelg i Tromsø - både til dagskonferanse og landsmøte.

Kontakt sekretariatet i LEVE for nærmere informasjon og påmel ding, tlf. 22502570 eller e-post: post@levenorge.no

\section{Nasjonal fagkonferanse "Etter selvmordet" 12.-13. okt.} i Oslo

For første gang arrangerer LEVE en nasjonal fagkonferanse om etterlatte ved sel vmord. Konferansen vil finne sted på Rikshospital et, hvor en rekke spennende og interessante temaer vil bli tatt opp. Mer info kommer i neste $\mathrm{nr}$. 